\title{
MOTIVASI MEMEDIASI PENGARUH KOMITMEN PROFESIONAL TERHADAP KEPUASAN KERJA PERAWAT RSUD KABUPATEN KLUNGKUNG
}

\author{
Nyoman Yustiana Sumandari ${ }^{1}$ \\ I Made Artha Wibawa ${ }^{2}$ \\ ${ }^{1,2}$ Fakultas Ekonomi dan Bisnis Universitas Udayana (Unud), Bali, Indonesia \\ email: sumandariyustiana@gmail.com
}

\begin{abstract}
ABSTRAK
Kepuasan kerja seseorang dipengaruhi oleh beberapa aspek, yaitu memiliki motivasi serta komitmen profesional yang diperlukan untuk mendorong seorang profesional dalam melakukan pekerjaannya dan mengembangkan kemampuan yang dimilikinya dalam melakukan pekerjaan. Penelitian ini dilakukan di Rumah Sakit Umum Daerah Kabupaten Klungkung dengan 120 perawat PNS sebagai sampel dengan metode penentuan sampel nonprobability sampling. Pengumpulan data menggunakan kuesioner. Data dianalisis dengan analisis jalur. Hasil penelitian menunjukan bahwa Komitmen Profesional berpengaruh positif dan signifikan terhadap Kepuasan Kerja; Motivasi Kerja memiliki pengaruh positif dan signifikan terhadap Kepuasan Kerja; Komitmen Profesional memiliki pengaruh positif dan signifikan terhadap Motivasi Kerja; serta Komitmen Profesional berpengaruh positif dan signifikan terhadap Kepuasan Kerja Perawat dimediasi Motivasi Kerja.
\end{abstract}

Kata kunci : Komitmen Profesional, Motivasi, Kepuasan Kerja

\section{ABSTRACT}

A person's job satisfaction is influenced by several aspects, such as having the motivation and professional commitment needed to encourage a professional to do his job and develop the abilities he has in doing his job. This research is conducted at the Klungkung District General Hospital with 120 civil servant nurses as a sample using nonprobability sampling method. Data were collected using a questionnaire and analyzed by path analysis. The results show that Professional Commitment has a positive and significant effect on Job Satisfaction; Work Motivation has a positive and significant effect on Job Satisfaction; Professional Commitment has a positive and significant effect on Work Motivation; and Professional Commitment has a positive and significant effect on Nurse Job Satisfaction mediated by Work Motivation.

Keywords: Professional Commitment, Motivation, Job Satisfaction 


\section{PENDAHULUAN}

Sumber Daya Manusia (SDM) merupakan salah satu dari beberapa aspek yang memiliki peran penting bahkan tidak dapat dilepaskan dari sebuah organisasi. SDM yang dalam hal ini adalah perawat merupakan asset rumah sakit yang harus dijaga dan juga harus dipelihara agar perawat yang berkualitas yang ada di rumah sakit tetap berada di rumah sakit tersebut (Kurniawan \& Satrya, 2020). Dalam mewujudkan agar perawat yang berkualitas yang ada di rumah sakit tetap berada di rumah sakit tersebut, maka perawat harus memiliki perasaan puas terhadap pekerjaannya.

Teori perubahan sosial menyatakan bahwa kepuasan kerja adalah pekerja merasa puas dengan pekerjaannya, mereka akan membalasnya dengan membantu rekan kerjanya bahkan ia tidak sungkan untuk mengerjakan tugas tambahan yang bukan bagian dari kewajibannya (Sablonnière, 2017). Kepuasan kerja merupakan wujud dari persepsi seseorang yang tercermin dalam sikap dan terfokus pada perilaku terhadap pekerjaan. Sehingga akan berdampak pada tingginya tingkat komitmen seseorang dalam berorganisasi dan tingginya pula tingkat produktivitas seseorang dalam bekerja (Saputra \& Suwandana, 2020)

Kepuasan kerja seseorang dipengaruhi oleh beberapa aspek, yaitu memiliki motivasi dalam dirinya yang diperlukan untuk mendorong sutau profesi dalam melakukan pekerjaannya dan mengembangkan kemampuan yang dimilikinya dalam melakukan pekerjaan (Jalagat, 2016). Aspek lain yang biasanya dapat mempengaruhi kepuasan kerja seseorang dalam adalah sebuah komitmen yang dimilikinya yaitu komitmen profesional, perawat yang berkomitmen dan berkualitas biasanya selalu dapat diandalkan dan akan mencurahkan kemampuannya secara maksimal (Chang et al., 2019). Adanya orientasi profesional akan mendasari timbulnya komitmen profesional yang juga mempengaruhi kepuasan kerja perawat, kepuasan merupakan suatu persepsi yang berisikan loyalitas dan harapan seseorang yang dituntun oleh suatu system nilai norma, yang akan mengarahkan orang tersebut untuk melakukan tindakan atau pekerjaannya sesuai dengan prosedur yang ada dalam upaya menjalankan tugasnya dengan tingkat keberhasilan yang tinggi (Mitchell et al., 2019). Salah satu tenaga kerja profesional yang dalam melakukan pekerjaanya harus memiliki rasa puas yang tinggi adalah tenaga medis perawat di rumah sakit. Dimana rumah sakit sebagai salah satu penyedia jasa pelayanan harus mengetahui bahwa konsumen sebagai pengguna jasa berharap mendapatkan pelayanan dengan kualitas terbaik (Febrianti, 2019).

Setelah dilakukan studi pendahuluan dengan mengobservasi dan melakukan wawancara di RSUD Kabupaten Klungkung terhadap delapan orang perawat mereka pada umumnya mengatakan masih belum puas dengan gaji yang mereka terima mengingat beban kerja dan resiko yang mereka hadapi tidak seimbang dengan gaji yang mereka dapatkan apalagi pada masa pandemi covid 19. Selain itu, masih terlihat beberapa perawat datang terlambat pada saat shift mereka bekerja, hal ini menunjukkan bahwa ada masalah yang terjadi terkait etika mereka dalam bekerja. Melihat dari sisi perawat ada dua orang perawat dari delapan orang perawat yang diwawancarai mengatakan jika ada peluang untuk bisa bekerja dirumah sakit lain dengan reward yang lebih menjanjikan dari rumah sakit umum Daerah 
Klungkung maka ia punya pertimbangan untuk pindah ke rumah sakit tersebut. Dengan demikian terdapat masalah dan fenomena yang perlu diselesaikan terkait dengan kepuasan kerja, sehingga perlu dilakukan penelitian tentang peran motivasi dalam memediasi pengaruh komitmen profesional terhadap kepuasan kerja perawat rumah sakit umum daerah Kabupaten Klungkung.

Komitmen profesional mendasari perilaku, sikap, dan orientasi seseorang dalam menjalankan tugasnya atau pekerjaannya, sedangkan motivasi merupakan keadaan pada diri seseorang yang mendorong keinginan individu untuk melakukan hal-hal tertentu guna mencapai suatu tujuan (Pradhana \& Rasmini, 2020). Akbar et al. (2017) mendefinisikan komitmen adalah kecintaan dan kesetiaan yang terdiri dari penyatuan dengan tujuan dan nilai-nilai perusahaan, keinginan untuk tetap berada dalam organisasi dan kesediaan untuk bekerja keras atas nama organisasi. Komitmen profesional akan mempengaruhi motivasi menjadi seorang profesional sebagai suatu kebanggan dalam suatu asosiasi profesi.

Penelitian Fauzia \& Sutrisno (2019) menyatakan komitmen profesional mempunyai pengaruh signifikan terhadap kepuasan kerja perawat, dengan menunjukkan komitmen terhadap profesi yang dijalani maka perawat mengharapkan adanya pengakuan sebagai profesional oleh rumah sakit dan masyarakat. Pengakuan sebagai profesional oleh organisasi dan masyarakat akan menimbulkan perasaan bangga dan mendorong timbulnya kepuasan kerja, juga terdapat pengaruh komitmen profesional berpengaruh terhadap kepuasan kerja, artinya bahwa dengan semakin meningkatnya komitmen profesional maka kepuasan kerja auditor akan mengalami peningkatan. Peningkatan komitmen profesional tersebut ditunjukkan dengan adanya peningkatan pengetahuan, mendukung organisasi profesi. Sari \& Dewi (2018) dalam penelitiannya menemukan bahwa komitmen profesional berpengaruh positif dan signifikan terhadap kepuasan kerja pegawai UPT Dinas Kesehatan Puskesmas Air Bangis. Berdasarkan penjelasan tersebut peneliti mengajukan hipotesis sebagai berikut $\mathrm{H}_{1}$ : Komitmen profesional berpengaruh positif terhadap kepuasan kerja

Komitmen profesional memiliki pengaruh signifikan terhadap motivasi. Dengan kata lain dapat dikatakan bahwa perawat dengan komitmen profesional yang tinggi akan memiliki motivasi kerja yang tinggi (Sulistyawati, 2016). Komitmen profesional mendasari perilaku, sikap dan orientasi profesional seseorang dalam menjalankan tugas atau pekerjaannya, sedangkan motivasi adalah keadaan pribadi seseorang yang mendorong keinginan individu melakukan kegiatan tertentu guna mencapai suatu tujuan. Hal ini berarti semakin meningkat komitmen profesional, motivasi seseorang dalam bekerja akan meningkat khususnya guna mendapatkan predikat sebagai seorang professional (Akase et al., 2021). Komitmen profesional dengan indikator tingkat pendidikan, pelatihan yang telah dilakukan perawat, tingkat disiplin dan semangat kerja serta kreativitas perawat merupakan salah satu faktor yang mempunyai pengaruh yang positif tetapi tidak signifikan terhadap kepuasan kerja. Hal ini berarti komitmen profesional mempunyai pengaruh positif dan signifikan terhadap motivasi (Darnawati \& Dewi, 2019). Berdasarkan penjelasan tersebut peneliti mengajukan hipotesis sebagai berikut.

$\mathrm{H}_{2}$ : Komitmen profesional berpengaruh positif terhadap motivasi. 
Hakikat kepuasan kerja adalah perasaan senang ataupun tidak senang terhadap pekerjaan yang dilakukannnya, perasaan senang dan tidak senang ini muncul yang disebabkan karena pada saat karyawan bekerja mereka membawa serta keinginan, kebutuhan dan pengalaman masa lalu yang membentuk harapan kerja mereka, semakin tinggi harapan kerja ini dapat terpenuhi, makin tinggi tingkat kepuasan kerja (Mahendra \& Suwandana, 2020). Hasil penelitian ini juga didukung oleh penelitian terdahulu yang menyatakan bahwa motivasi mempunyai pengaruh yang signifikan terhadap kepuasan kerja, hal ini menunjukan bahwa semakin tinggi motivasi yang dirasakan oleh perawat, maka akan meningkatkan kepuasan kerja perawat pada rumah sakit. Semakin tinggi motivasi kerja perawat maka semakin tinggi kepuasan kerja pada rumah sakit dan sebaliknya. Motivasi kerja merupakan dorongan terhadap perawat untuk melakukan pekerjaanya (Mus et al., 2018)

Penelitian lain menyatakan bahwa motivasi perawat sangat dibutuhkan untuk menjaga kepuasan kerja mereka selalu tinggi yang akan berpengaruh positif terhadap output kerja yang diberikan. Suatu rumah sakit yang terus memberikan dorongan motivasi akan memiliki perawat yang puas dengan pekerjaannya. Motivasi kerja secara langsung berpengaruh positif terhadap kepuasan kerja. motivasi timbul dari tujuan seseorang untuk memenuhi kepuasannya (Lantara, 2018). Seseorang yang tidak termotivasi dalam bekerja tidak dapat menjalani pekerjaannya dengan sepenuh hati, hal inilah yang sering menjadikan seseorang tidak berhasil dalam kariernya. Gambaran yang akurat tentang hubungan ini adalah bahwa motivasi kerja menyumbang timbulnya kepuasan kerja yang tinggi. Parimita et al. (2018) dan Poceratu (2018) membuktikan bahwa motivasi kerja mempunyai pengaruh positif terhadap kepuasan kerja. Berdasarkan penjelasan tersebut peneliti mengajukan hipotesis sebagai berikut.

$\mathrm{H}_{3}$ : Motivasi berpengaruh positif terhadap kepuasan kerja

Suatu komitmen profesional pada dasarnya merupakan persepsi yang berintikan loyalitas, tekad dan harapan perawat dengan dituntun oleh sistem nilai atau norma yang akan mengarahkan orang tersebut. Hasil dari penelitian terdahulu menyatakan bahwa motivasi kerja berpengaruh positif dan signifikan terhadap kepuasan kerja karyawan Bank Nagari (Can \& Yasri, 2016). Hal ini dapat menjadikan komitmen profesional sebagai gagasan yang mendorong motivasi seseorang dalam bekerja. Kepuasan kerja akan tinggi bila keinginan dan kebutuhan karyawan yang menjadikan motivasi kerja dapat terpenuhi. Kompensasi dari rumah sakit berupa penghargaan (reward) sesuai profesinya akan menimbulkan kepuasan kerja karena mereka merasa bahwa organisasi telah memperhatikan kebutuhan dan pengharapan kerja mereka. Komitmen profesional mempunyai pengaruh secara tidak langsung melalui variabel mediasi motivasi terhadap kepuasan kerja, dengan adanya motivasi kerja, maka semangat kerja para auditor profesional bersedia dan rela untuk mengerahkan kemampuan dalam bentuk keahlian, ketrampilan, tenaga dan waktu demi tanggung jawab terhadap profesinya (Sulistyawati, 2016). Komitmen profesional berpengaruh positif dan signifikan melalui motivasi sebagai variabel intervening terhadap kepuasan kerja (Sari \& Dewi, 2018). Berdasarkan penjelasan tersebut peneliti mengajukan hipotesis sebagai berikut. 
$\mathrm{H}_{4}$ : Motivasi memediasi pengaruh komitmen professional terhadap kepuasan kerja positif.

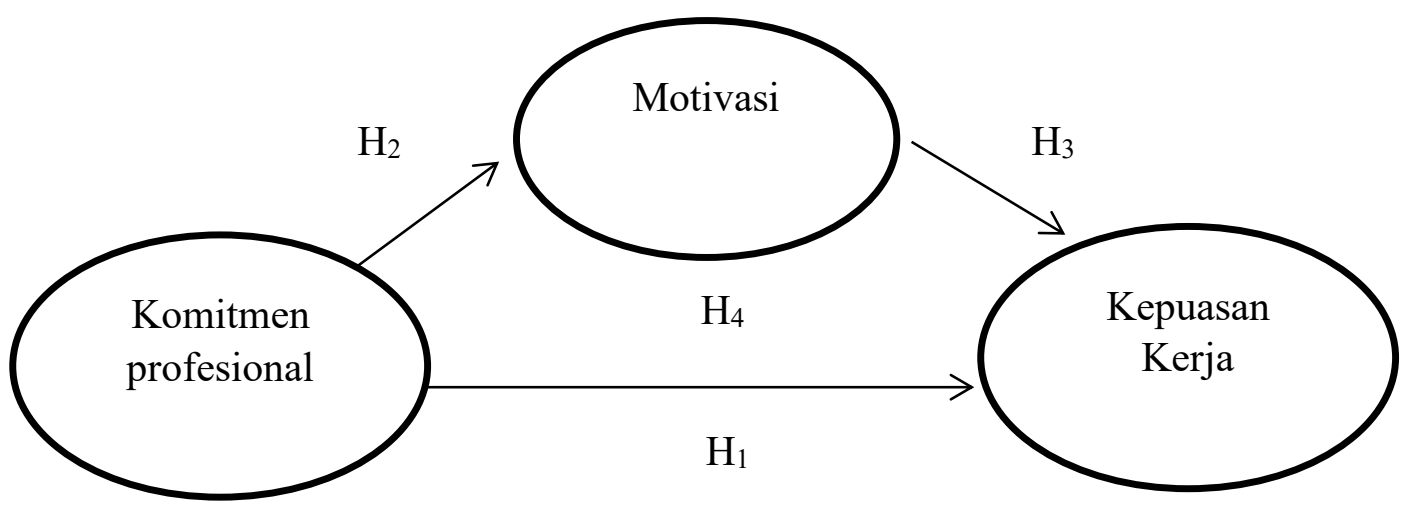

Gambar 1. Kerangka Konseptual

\section{METODE PENELITIAN}

Desain penelitian yang digunakan dalam penelitian ini adalah desain kuantitatif kausal. Lokasi penelitian yang digunakan yaitu Rumah Sakit Umum Daerah Kabupaten Klungkung. Lokasi dari RSUD Kab. Klungkung. Alasan memilih lokasi ini karna Rumah Sakit merupakan salah satu organisasi yang di dalamnya terdapat tenaga profesional diantaranya yaitu Dokter, Apoteker, Perawat, Bidan, Ahli Gizi, Analis dan lain sebagainya. Selain itu juga karena adanya adanya akses yang memudahkan peneliti mendapatkan informasi yang dibutuhkan dalam penelitian ini. Obyek dari penelitian ini yaitu motivasi, komitmen profesional, dan kepuasan kerja.

Kepuasan kerja dalam penelitian ini merupakan sikap emosional yang memiliki rasa senang serta cinta perawat RSUD Kab. Klungkung terhadap pekerjaanya. Indikator yang digunakan untuk mengukur kepuasan kerja seorang perawat yaitu: Pekerjaan itu sendiri $\left(\mathrm{Y}_{1}\right)$, Gaji/ Upah $\left(\mathrm{Y}_{2}\right)$, Promosi $\left(\mathrm{Y}_{3}\right)$, Pengawasan $\left(\mathrm{Y}_{4}\right)$, Rekan kerja $\left(\mathrm{Y}_{5}\right)$. Komitmen professional dalam penelitian adalah kekuatan relatif dari identifikasi dan keterlibatan perawat RSUD Kab. Klungkung terhadap suatu profesi. Indikator komitmen professional adalah Kompetensi $\left(\mathrm{X}_{1.1}\right)$, Efektivitas $\left(\mathrm{X}_{1.2}\right)$, Efisiensi $\left(\mathrm{X}_{1.3}\right)$. Motivasi dalam penelitian ialah dorongan yang dimiliki perawat di RSUD Kab. Klungkung untuk berbuat sesuatu. Indicator - indicator untuk mengetahui motivasi kerja perawat, yaitu: Fisiologis $\left(Z_{1}\right)$, Keamanan $\left(Z_{2}\right)$, Sosial $\left(Z_{3}\right)$, Penghargaan $\left(Z_{4}\right)$

Data kualitatif dalam penelitian ini adalah gambaran umum mengenai RSUD Kabupaten Klungkung dan data kuantitatif adalah skor jawaban responden dan jumlah perawat di RSUD Kabupaten Klungkung. Sumber primer merupakan data langsung dari responden. Sumber primer dalam penelitian yaitu data yang dikumpulkan secara langsung dari perawat di RSUD Kab.Klungkung. Instrumen dalam pemelitian ini adalah kuesioner yang diukur menggunakan skala Likert dengan skala 1 sampai 5. Populasi dalam penelitian ini adalah 120 perawat PNS di RSUD Kab. Klungkung pada tahun 2020, karena perawat lebih sering berinteraksi dengan pasien dibandingkan tenaga medis lainnya, tetapi balas jasa yang diberikan kepada perawat lebih rendah dibandingkan tenaga profesional lainnya. Di RSUD 
Kab. Klungkung terdapat perawat PNS dan kontrak. Namun dalam penelitian ini hanya meneliti perawat PNS, karena untuk kepuasan kerja susah untuk diteliti pada perawat kontrak. Sampel dalam penelitian ini yaitu seluruh perawat PNS yang berjumlah 120 di Rumah Sakit Umum Daerah Kabupaten Klungkung.Pengisian kuesioner akan dilakukan menggunakan google form karena sedang terjadinya pandemi Covid-19.

Metode penentuan sampel yang akan digunakan dalam penelitian ini yaitu menggunakan teknik nonprobability sampling dengan sampling jenuh. Data yang dikumpulkan dalam penelitian ini menggunakan metode wawancara dan kuesioner adalah metode pengumpulan data dengan menggunakan daftar pertanyaan yang disebarkan kepada responden mengenai komitmen profesional, motivasi dan kepuasan kerja. Data dianalisis dengan analisis jalur

\section{HASIL DAN PEMBAHASAN}

Data karakteristik responden adalah data responden yang dikumpulkan untuk mengetahui profil responden penelitian. Berdasarkan hasil penelitian yang dilakukan terhadap perawat Rumah Sakit Umum Daerah Kabupaten Klungkung dapat diketahui karakteristik respondennya meliputi jenis kelamin, usia, dan lama bekerja yang dijelaskan pada Tabel 1 .

Tabel 1.

Karakteristik Responden

\begin{tabular}{|c|c|c|c|c|}
\hline No & Variabel & Klasifikasi & $\begin{array}{l}\text { Jumlah } \\
\text { (orang) }\end{array}$ & $\begin{array}{c}\text { Persentase } \\
(\%)\end{array}$ \\
\hline \multirow[t]{3}{*}{1} & Jenis & Laki-Laki & 22 & 18,3 \\
\hline & Kelamin & Perempuan & 98 & 81,7 \\
\hline & & & 120 & 100 \\
\hline \multirow[t]{8}{*}{2} & & 25-40 Tahun & 4 & 3,3 \\
\hline & & 31-35 Tahun & 36 & 30,0 \\
\hline & & 36-40 Tahun & 33 & 377,5 \\
\hline & Usia & 41-45 Tahun & 17 & 14,2 \\
\hline & & 46-50 Tahun & 14 & 11,7 \\
\hline & & 51-55 Tahun & 11 & 9,2 \\
\hline & & $>55$ Tahun & 5 & 4,2 \\
\hline & & & 120 & 100 \\
\hline \multirow[t]{5}{*}{3} & & $<3$ Tahun & 7 & 5,8 \\
\hline & & 3-6 Tahun & 8 & 6,7 \\
\hline & Lama bekerja & 6-10 Tahun & 29 & 24,2 \\
\hline & & $>10$ Tahun & 76 & 63,3 \\
\hline & & & 120 & 100 \\
\hline
\end{tabular}

Sumber: Data primer diolah, 2020

Berdasarkan Tabel 1. dapat di lihat perawat Rumah Sakit Umum Daerah Kabupaten Klungkung yang di jadikan sampel sebanyak 120 orang. Jika di lihat dari jenis kelamin, jenis kelamin perempuan mendominasi dalam penelitian ini dengan presentase sebesar 81,7 persen, seperti yang kita ketahui bahwa banyak lakilaki menganggap bahwa perawat itu adalah tugas seorang wanita karna tugas perawat adalah merawat. Jika di lihat dari usia, yang memiliki usia 31-35 tahun mendominasi dengan presentase sebesar 30 persen. Di lihat dari perkerjaan 
responden yang bekerja selama lebih dari 10 Tahun mendominasi dengan persentase sebesar 63,3 persen

Tabel 2.

Hasil Uji Validitas

\begin{tabular}{ccc}
\hline Variabel & Instrumen & Pearson Correlation \\
& & \\
\hline \multirow{2}{*}{ Kepuasan Kerja (Y) } & Y1 & 0,781 \\
& Y2 & 0,720 \\
& Y3 & 0,811 \\
Komitmen Profesional $(\mathrm{X})$ & $\mathrm{Y} 5$ & 0,700 \\
& $\mathrm{X} 1.1$ & 0,517 \\
& $\mathrm{X} 1.2$ & 0,491 \\
& $\mathrm{X} 2.1$ & 0,619 \\
& $\mathrm{X} 2.2$ & 0,768 \\
& $\mathrm{X} 3.1$ & 0,805 \\
& $\mathrm{X} 3.2$ & 0,676 \\
& $\mathrm{Z} 1$ & 0,782 \\
Motivasi Kerja $(\mathrm{Z})$ & $\mathrm{Z} 2$ & 0,934 \\
& $\mathrm{Z} 3$ & 0,521 \\
& $\mathrm{Z} 4$ & 0,761 \\
& & 0,760 \\
\hline
\end{tabular}

Sumber: Data primer diolah, 2020

Dapat disimpulkan pada Tabel 2. bahwa seluruh instrumen variabel penelitian berupa komitmen profesional, motivasi kerja dan kepuasan kerja telah memenuhi syarat uji validitas yang dimana nilai skor total pearson correlation masing-masing instrumen berada diatas 0,30, maka instrumen layak digunakan menjadi alat ukur variabel-variabel tersebut.

Tabel 3.

Uji Reliabilitas

Variabel

Cronbach's Alpha

\begin{tabular}{lc}
\hline Kepuasan Kerja (Y) & 0,752 \\
Komitmen Profesional (X) & 0,758 \\
Motivasi Kerja (Z) & 0,752
\end{tabular}

Sumber: Data primer diolah, 2020

Tabel 3. ditampilkan uji reliabilitas pada masing-masing variabel berada pada titik diatas 0,60 yang ditunjukkan pada hasil Cronbach's Alpha, maka dapat dikatakan seluruh instrumen telah memenuhi syarat reliabilitas. 
Tabel 4.

Deskripsi Jawaban Responden Terhadap Kepuasan Kerja

\begin{tabular}{|c|c|c|c|c|c|c|c|c|}
\hline \multirow{2}{*}{ No } & \multirow{2}{*}{ Pernyataan } & \multicolumn{5}{|c|}{$\begin{array}{c}\text { Jawaban Responden } \\
\text { (orang) }\end{array}$} & \multirow{2}{*}{$\begin{array}{l}\text { Rata- } \\
\text { rata }\end{array}$} & \multirow{2}{*}{ Kriteria } \\
\hline & & 1 & 2 & 3 & 4 & 5 & & \\
\hline 1 & $\begin{array}{lcr}\text { Saya senang } & \text { dengan } \\
\text { pekerjaan saya } & \text { sebagai } \\
\text { perawat di } & \text { RSUD } \\
\text { Kab.Klungkung } & \left(\mathrm{Y}_{1}\right) \text {. }\end{array}$ & 0 & 0 & 3 & 53 & 64 & 4.51 & Sangat Baik \\
\hline 2 & $\begin{array}{l}\text { Gaji yang saya terima } \\
\text { memotivasi saya untuk } \\
\text { bekerja lebih baik RSUD } \\
\text { Kab.Klungkung }\left(\mathrm{Y}_{2}\right) \text {. }\end{array}$ & 0 & 1 & 20 & 66 & 33 & 4.09 & Baik \\
\hline 3 & $\begin{array}{l}\text { Saya puas dengan adanya } \\
\text { dukungan atasan saya di } \\
\text { RSUD } \quad \text { Kab.Klungkung } \\
\left(\mathrm{Y}_{3}\right) .\end{array}$ & 0 & 4 & 27 & 64 & 25 & 3.92 & Baik \\
\hline 4 & $\begin{array}{l}\text { Seluruh perawat PNS } \\
\text { mendapatkan kesempatan } \\
\text { yang sama dalam promosi } \\
\text { jabatan di RSUD } \\
\text { Kab.Klungkung }\left(\mathrm{Y}_{4}\right) \text {. }\end{array}$ & 0 & 10 & 26 & 70 & 14 & 3.73 & Baik \\
\hline 5 & $\begin{array}{l}\text { Saya tidak memiliki } \\
\text { masalah dalam bekerja } \\
\text { bersama perawat yang lain } \\
\text { di RSUD Kab.Klungkung } \\
\left(\mathrm{Y}_{5}\right) \text {. }\end{array}$ & 0 & 0 & 12 & 62 & 46 & 4.28 & Sangat Baik \\
\hline & Rata-rat & & & & & & 4,11 & Baik \\
\hline
\end{tabular}

Sumber: Data primer diolah, 2020

Tabel 4. menjelaskan bahwa persepsi responden mengenai variabel kepuasan kerja yang memiliki rata-rata sebesar 4,11 yang termasuk kriteria baik yang dalam hal ini mengindentifikasikan bahwa perawat yang ada di RSUD Kab.Klungkung memiliki tingkat kepuasan kerja yang baik. Dari lima indikator variabel, terdapat tiga indikator variabel yang berada di bawah rata-rata yaitu "gaji yang saya terima memotivasi saya untuk bekerja lebih baik RSUD Kab.Klungkung" dengan rata-rata 4,09, "saya puas dengan adanya dukungan atasan saya di RSUD Kab.Klungkung" dengan rata-rata 3,92 dan indikator variabel "seluruh perawat PNS mendapatkan kesempatan yang sama dalam promosi jabatan di RSUD Kab.Klungkung" dengan rata-rata 3,73. Pernyataan yang berada di atas rata-rata yaitu "saya senang dengan pekerjaan saya sebagai perawat di RSUD Kab.Klungkung” dengan rata-rata 4.51 dan indikator variable, "saya tidak memiliki masalah dalam bekerja bersama perawat yang lain di RSUD Kab.Klungkung" dengan rata-rata 4.28.

Variabel kepuasan kerja yang memiliki rata-rata terendah adalah pernyataan "Seluruh perawat PNS mendapatkan kesempatan yang sama dalam promosi jabatan di RSUD Kab.Klungkung", diperoleh nilai rata-rata sebesar 3,73 yang masuk 
kriteria baik, tetapi memiliki nilai rata-rata yang rendah dibandingkan dengan pernyataan yang lainnya ini berarti secara umum responden belum mendapatkan kesempatan yang sama dalam promosi jabatan di RSUD Kab.Klungkung. Variabel kepuasan kerja yang memiliki rata-rata tertinggi adalah pernyataan "Saya senang dengan pekerjaan saya sebagai perawat di RSUD Kab.Klungkung”, diperoleh nilai rata-rata sebesar 4,51 yang masuk kriteria sngat baik, ini berarti secara umum responden merasa senang dengan pekerjaan mereka sebagai perawat di RSUD Kab.Klungkung.

Tabel 5.

Deskripsi Jawaban Responden Terhadap Komitmen Profesional

\begin{tabular}{|c|c|c|c|c|c|c|c|c|}
\hline \multirow{2}{*}{ No } & \multirow{2}{*}{ Pernyataan } & \multicolumn{5}{|c|}{$\begin{array}{l}\text { Jawaban Responden } \\
\text { (orang) }\end{array}$} & \multirow{2}{*}{$\begin{array}{l}\text { Rata- } \\
\text { rata }\end{array}$} & \multirow{2}{*}{ Kriteria } \\
\hline & & 1 & 2 & 3 & 4 & 5 & & \\
\hline \multirow[t]{2}{*}{1} & Hasil pekerjaan saya sesuai dengan standar & & & & & & & \\
\hline & $\begin{array}{l}\text { kualitas Perawat RSUD Kab.Klungkung } \\
\left(\mathrm{X}_{1.1}\right) \text {. }\end{array}$ & 0 & 2 & 11 & 69 & 38 & 4.19 & Baik \\
\hline 2 & $\begin{array}{l}\text { Saya akan menerima apapun jenis pekerjaan } \\
\text { yang ditugaskan untuk dapat terus bekerja di } \\
\text { RSUD Kab. Klungkung }\left(\mathrm{X}_{1.2}\right)\end{array}$ & 3 & 29 & 21 & 54 & 13 & 3.38 & $\begin{array}{l}\text { Cukup } \\
\text { Baik }\end{array}$ \\
\hline 3 & $\begin{array}{l}\text { Saya menyelesaikan tugas karena saya } \\
\text { merasa memiliki tanggungjawab di RSUD } \\
\text { Kab.Klungkung }\left(\mathrm{X}_{2.1}\right)\end{array}$ & 0 & 0 & 4 & 58 & 58 & 4.45 & $\begin{array}{l}\text { Sangat } \\
\text { Baik }\end{array}$ \\
\hline 4 & $\begin{array}{l}\text { Saya ingin melakukan usaha yang luar biasa } \\
\text { melebihi yang diharapkan demi kesuksesan } \\
\text { profesi perawat di RSUD Kab.Klungkung } \\
\left(\mathrm{X}_{2.2 .}\right) \text {. }\end{array}$ & 0 & 3 & 28 & 64 & 25 & 3.93 & Baik \\
\hline \multirow{3}{*}{$\begin{array}{l}5 \\
6\end{array}$} & Saya selalu hadir tepat waktu $\left(\mathrm{X}_{3.1}\right)$ & 0 & 1 & 16 & 71 & 32 & 4.12 & Baik \\
\hline & $\begin{array}{l}\text { Profesi perawat menginspirasi saya untuk } \\
\text { bekerja dengan sebaik-baiknya di RSUD } \\
\text { Kab.Klungkung }\left(\mathrm{X}_{3.2}\right) \text {. }\end{array}$ & 0 & 0 & 6 & 70 & 44 & 4.32 & $\begin{array}{c}\text { Sangat } \\
\text { Baik }\end{array}$ \\
\hline & Rata-rata & & & & & & 4,06 & Baik \\
\hline
\end{tabular}

Sumber: Data primer diolah, 2020

Tabel 5. menunjukkan persepsi responden mengenai variabel komitmen profesional yang memiliki rata-rata 4,06 yang masuk kriteria baik. Dari kelima indikator terdapat dua indikator variabel yang berada di bawah rata-rata, yaitu "saya akan menerima apapun jenis pekerjaan yang ditugaskan untuk dapat terus bekerja di RSUD Kab. Klungkung” dengan rata-rata 3,38 dan indikator variabel "saya ingin melakukan usaha yang luar biasa melebihi yang diharapkan demi kesuksesan profesi perawat di RSUD Kab.Klungkung” dengan rata-rata 3,93. Pernyataan yang berada di atas rata-rata yaitu hasil pekerjaan saya sesuai dengan standar kualitas Perawat RSUD Kab.Klungkung dengan rata-rata 4,19, "saya menyelesaikan tugas karena saya merasa memiliki tanggungjawab di RSUD Kab.Klungkung" yang memproleh rata-rata 4,45, indikator "saya selalu hadir tepat waktu" dengan ratarata 4,12 dan profesi perawat menginspirasi saya untuk bekerja dengan sebaikbaiknya di RSUD Kab.Klungkung dengan rata-rata 4,32. 
Variabel komitmen profesional yang memiliki rata-rata terendah adalah pernyataan "Saya akan menerima apapun jenis pekerjaan yang ditugaskan untuk dapat terus bekerja di RSUD Kab. Klungkung", diperoleh nilai rata-rata sebesar 3,38 yang masuk kriteria cukup baik, tetapi memiliki nilai rata-rata yang rendah dibandingkan dengan pernyataan yang lainnya ini berarti secara umum responden tidak akan menerima apapun jenis pekerjaan yang ditugaskan untuk dapat terus bekerja di RSUD Kab. Klungkung. Variabel komitmen profesional yang memiliki rata-rata tertinggi adalah pernyataan "Saya menyelesaikan tugas karena saya merasa memiliki tanggungjawab di RSUD Kab.Klungkung", diperoleh nilai ratarata sebesar 4,45 yang masuk kriteria sangat baik, ini berarti secara umum perawat menyelesaikan tugas karena mereka merasa memiliki tanggungjawab di RSUD Kab.Klungkung.

Tabel 6.

Deskripsi Jawaban Responden Terhadap Motivasi Kerja

\begin{tabular}{|c|c|c|c|c|c|c|c|c|}
\hline \multirow{2}{*}{ No } & \multirow{2}{*}{ Pernyataan } & \multicolumn{5}{|c|}{$\begin{array}{c}\text { Jawaban Responden } \\
\text { (orang) }\end{array}$} & \multirow{2}{*}{$\begin{array}{c}\text { Rata- } \\
\text { rata }\end{array}$} & \multirow{2}{*}{ Kriteria } \\
\hline & & 1 & 2 & 3 & 4 & 5 & & \\
\hline 1 & $\begin{array}{l}\text { Saya merasa termotivasi dengan } \\
\text { jasa pelayanan yang saya } \\
\text { dapatkan di RSUD Kab. } \\
\text { Klungkung }\left(Z_{1}\right) \text {. }\end{array}$ & 0 & 9 & 26 & 64 & 21 & 3.81 & Baik \\
\hline 2 & $\begin{array}{l}\text { Saya merasa membutuhkan } \\
\text { keamanan dan keselamatan, } \\
\text { antara lain keselamatan dan } \\
\text { perlindungan dalam bekerja } \\
\text { sebagai perawat di RSUD } \\
\text { Kab.Klungkung }\left(Z_{2}\right) \text {. }\end{array}$ & 0 & 0 & 1 & 50 & 69 & 4.57 & $\begin{array}{c}\text { Sangat } \\
\text { Baik }\end{array}$ \\
\hline 3 & $\begin{array}{l}\text { Lingkungan kerja mebuat saya } \\
\text { termotivasi untuk bekerja lebih } \\
\text { baik di RSUD Kab.Klungkung } \\
\left(\mathrm{Z}_{3}\right)\end{array}$ & 0 & 0 & 11 & 75 & 34 & 4.19 & Baik \\
\hline 4 & $\begin{array}{l}\text { Saya senang diberikan pujian } \\
\text { atas apa yang saya kerjakan di } \\
\text { RSUD Kab.Klungkung }\left(Z_{4}\right) \text {. }\end{array}$ & 0 & 3 & 33 & 61 & 23 & 3.87 & Baik \\
\hline & Rata-rat & & & & & & 4,11 & Baik \\
\hline
\end{tabular}

Sumber: Data primer diolah, 2020

Tabel 6. menunjukkan persepsi responden mengenai variabel motivasi kerja yang memiliki rata-rata 4,11 yang masuk kriteria baik. Terdapat dua indikator variabel yang di bawah rata-rata yaitu "saya merasa termotivasi dengan jasa pelayanan yang saya dapatkan di RSUD Kab. Klungkung” dengan rata-rata 3,81 dan indikator "saya senang diberikan pujian atas apa yang saya kerjakan di RSUD Kab.Klungkung" dengan rata-rata 3,87. Pernyataan yang berada di atas rata-rata terdapat dua, yaitu indikator "saya merasa membutuhkan keamanan dan keselamatan, antara lain keselamatan dan perlindungan dalam bekerja sebagai perawat di RSUD Kab.Klungkung" dengan rata-rata 4,57 dan "lingkungan kerja membuat saya termotivasi untuk bekerja lebih baik di RSUD Kab.Klungkung” yang memperoleh rata-rata sebesar 4,19. 
Variabel motivasi kerja yang memiliki rata-rata terendah adalah pernyataan "saya merasa termotivasi dengan jasa pelayanan yang saya dapatkan di RSUD Kab. Klungkung", diperoleh nilai rata-rata sebesar 3,81 yang masuk kriteria baik, tetapi memiliki nilai rata-rata yang rendah dibandingkan dengan pernyataan yang lainnya ini berarti secara umum responden menganggap belum termotivasi atas jasa pelayanan yang didapat. Variabel motivasi kerja yang memiliki rata-rata tertinggi adalah pernyataan "Saya merasa membutuhkan keamanan dan keselamatan, antara lain keselamatan dan perlindungan dalam bekerja sebagai perawat di RSUD Kab.Klungkung”, diperoleh nilai rata-rata sebesar 4,57 yang masuk kriteria baik, ini berarti secara umum responden merasa membutuhkan keamanan dan keselamatan, antara lain keselamatan dan perlindungan dalam bekerja sebagai perawat di RSUD Kab.Klungkung.

Tabel 7.

Uji Normalitas

\begin{tabular}{ll}
\hline Persamaan & Asymp. Sig. (2-tailed) \\
\hline Substruktur 1 & 0,087 \\
Substruktur 2 & 0,095 \\
\hline
\end{tabular}

Sumber: Data primer diolah, 2020

Berdasarkan uji normalitas dengan menggunakan One-Sample KolmogorovSmirnov Test yang ditampilkan pada Tabel 7. tersebut menunjukkan bahwa besarnya nilai Asymp. Sig. (2-tailed) Kolmogorov-Smirnov adalah sebesar 0,087 dan 0,095. Nilai Asymp. Sig. (2-tailed) Kolmogorov-Smirnov tersebut lebih besar dibandingkan dengan nilai alpha sebesar 0,05 maka mengindikasikan bahwa data yang digunakan pada penelitian ini terdistribusi normal, sehingga dapat disimpulkan bahwa model memenuhi asumsi normalitas

Tabel 8

Uji Multikolinieritas

\begin{tabular}{|c|c|c|c|}
\hline & \multirow{2}{*}{ Model } & \multicolumn{2}{|c|}{ Collinearity Statistics } \\
\hline & & Tolerance & $V I F$ \\
\hline \multirow{2}{*}{ Substruktur2 } & Komitmen Profesional & 0,653 & 1,532 \\
\hline & Motivasi Kerja & 0,653 & 1,532 \\
\hline
\end{tabular}

Sumber: Data primer diolah, 2020

Berdasarkan Tabel 8. tersebut ditunjukkan bahwa tidak terdapat variabel bebas yang memiliki nilai tolerance kurang dari 0,10 nilai tolerance masingmasing variable adalah 0,653 dan juga tidak ada variabel bebas yang memiliki nilai VIF lebih dari 10, dan nilai VIF adalah 1,532 Maka dari pada itu model regresi bebas dari gejala multikoleniaritas. 
Tabel 9.

Uji Heteroskedastisitas

\begin{tabular}{cllr}
\hline Persamaan & \multicolumn{1}{c}{ Model } & T & Sig. \\
\hline Substruktur1 & Komitmen Profesional & -0.007 & 0.994 \\
Substruktur 2 & Komitmen Profesional & -0.066 & 0.948 \\
& Motivasi Kerja & -0.764 & 0.446 \\
\hline Sumber: Data primer
\end{tabular}

Sumber: Data primer diolah, 2020

Berdasarkan Tabel 9. tersebut, ditunjukkan bahwa masing-masing model memiliki nilai signifikansi yaitu $(0,994,0,948$ dan 0,446$)$ dimana nilai signifikan tersebut lebih besar dari 5\% $(0,05)$. Hal ini menunjukkan bahwa variabel bebas yang digunakan pada penelitian ini tidak berpengaruh secara signifikan terhadap variabel terikatnya yaitu absolute error, maka dari itu, penelitian ini bebas dari gejala heteroskedastisitas.

Tabel 10.

Hasil Analisis Jalur Pada Struktur 1

\begin{tabular}{|c|c|c|c|c|c|}
\hline \multirow{2}{*}{ Model } & \multicolumn{2}{|c|}{ Unstandardized Coefficients } & \multirow{2}{*}{$\begin{array}{c}\begin{array}{c}\text { Standardized } \\
\text { Coefficients }\end{array} \\
\text { Beta }\end{array}$} & \multirow[t]{2}{*}{$\mathbf{t}$} & \multirow[t]{2}{*}{ Sig. } \\
\hline & $\mathbf{B}$ & Std. Error & & & \\
\hline (Constant) & 1.750 & 0.300 & & 5.834 & 0.000 \\
\hline Komitmen Profesional & 0.581 & 0.073 & 0.589 & 7.921 & 0.000 \\
\hline $\begin{array}{ll}R^{2} & : 0,347\end{array}$ & & & & & \\
\hline
\end{tabular}

Sumber: Data primer diolah, 2020

Berdasarkan hasil analisis jalur pada Tabel 10. maka dapat dirumuskan persamaan struktural yang terbentuk adalah sebagai berikut.

$\mathrm{Y}=\mathrm{a}+\mathrm{b}_{1} \mathrm{X}+\mathrm{e}_{2}$

$\mathrm{Y}=1.750+0,581 \mathrm{X}_{1}+\mathrm{e}_{2}$

Variabel komitmen profesional memiliki koefisien sebesar 0,5891 berarti komitmen profesional memiliki pengaruh positif terhadap motivasi kerja perawat RSUS Kab. Klungkung.

Tabel 11.

Hasil Analisis Jalur Pada Struktur 2

\begin{tabular}{|c|c|c|c|c|c|}
\hline \multirow{2}{*}{ Model } & \multicolumn{2}{|c|}{$\begin{array}{c}\text { Unstandardized } \\
\text { Coefficients }\end{array}$} & \multirow{2}{*}{$\begin{array}{c}\text { Standardized } \\
\text { Coefficients }\end{array}$} & \multirow[t]{2}{*}{$\mathbf{t}$} & \multirow[t]{2}{*}{ Sig. } \\
\hline & $\mathrm{B}$ & Std. Error & & & \\
\hline (Constant) & 0.757 & 0.260 & & 2.910 & 0.004 \\
\hline Komitmen Profesional & 0.444 & 0.069 & 0.470 & 6.415 & 0.000 \\
\hline Motivasi Kerja & 0.376 & 0.070 & 0.391 & 5.345 & 0.000 \\
\hline $\mathrm{R}^{2} \quad: 0,590$ & & & & & \\
\hline
\end{tabular}


Berdasarkan hasil analisis jalur pada Tabel 11. maka dapat dirumuskan persamaan struktural yang terbentuk adalah sebagai berikut.

$\mathrm{Y}=\mathrm{a}+\mathrm{b}_{1} \mathrm{X}+\mathrm{b}_{2} \mathrm{Z}+\mathrm{e}_{1}$

$\mathrm{Y}=0.757+0.444 \mathrm{X}+0.376 \mathrm{Z}+\mathrm{e}_{1}$

Variabel komitmen profesional memiliki koefisien sebesar 0,444 berarti Komitmen Profesional memiliki pengaruh positif terhadap kepuasan kerja. Variabel motivasi kerja memiliki koefisien sebesar 0,376 berarti motivasi kerja memiliki pengaruh positif terhadap kepuasan kerja perawat RSUD Kab. Klungkung.

Pada perhitungan nilai koefisien determinasi total didapatkan sebesar 0,732, maka kesimpulannya adalah 73,2\% variabel Kepuasan Kerja peawat Rumah Sakit Umum Daerah Kabupaten Klungkung dipengaruhi oleh komitmen profesional, dan motivasi kerja, sedangkan sisanya26,8\% dipengaruhi oleh faktor lain yang tidak dimasukkan dalam model penelitian atau diluar model penelitian

Tabel 12.

Pengaruh Langsung, Pengaruh Tidak Langsung Komitmen Profesional (X), Terhadap Motivasi Kerja (Z) dan Kepuasan Kerja (Y).

\begin{tabular}{lccc}
\hline \multicolumn{1}{c}{ Pengaruh variabel } & $\begin{array}{c}\text { Pengaruh } \\
\text { langsung }\end{array}$ & $\begin{array}{c}\text { Pengaruh tidak } \\
\text { langsung melalui } \mathbf{Z}\end{array}$ & Pengaruh Total \\
\hline $\mathrm{X} \rightarrow \mathrm{Z}$ & 0,589 & & 0,589 \\
$\mathrm{Z} \rightarrow \mathrm{Y}$ & 0,391 & 0,230 & 0,391 \\
$\mathrm{X} \rightarrow \mathrm{Y}$ & 0,470 & & 0,700 \\
\hline
\end{tabular}

Sumber: Data primer diolah, 2020

Pada penelitian yang dilakukan terhadap perawat Rumah Sakit Umum Daerah Kabupaten Klungkung tentang pengaruh komitmen profesional terhadap motivasi kerja, maka didapatkan hasil komitmen profesional memiliki pengaruh langsung terhadap Motivasi Kerja sebesar 0,589. Hasil komitmen profesional memiliki pengaruh langsung terhadap kepuasan kerja sebesar 0,470. Motivasi kerja memiliki pengaruh langsung terhadap kepuasan kerja sebesar 0,391. Komitmen profesional memiliki pengaruh langsung dan tidak langsung melalui motivasi kerja terhadap kepuasan kerja dengan nilai koefisien masing-masing sebesar 0,470 dan 0,230, sehingga besaran pengaruh totalnya adalah 0,700

Komitmen Profesional memiliki nilai Beta sebesar 0,470 dan nilai Sig. sebesar 0,000, maka dapat dikatakan $\mathrm{H}_{1}$ diterima karena nilai Sig. 0,000<0,05. Kesimpulannya adalah komitmen profesional berpengaruh positif dan signifikan terhadap kepuasan kerja dengan kata lain semakin meningkat komitmen profesional maka kepuasan kerja perawat Rumah Sakit Umum Daerah Kabupaten Klungkung, sehingga hipotesis pertama diterima. Komitmen profesional terhadap kepuasan kerja perawat di RSUD Kab. Klungkung mendapat hasil yang positif dan signifikan karena didukung oleh hasil pekerjaan perawat yang sesuai dengan standar kualitas perawat di RSUD Kab.Klungkung, perawat dapat menyelesaikan tugas karena merasa memiliki tanggungjawab di RSUD Kab.Klungkung, perawat selalu hadir tepat waktu, profesi perawat menginspirasi untuk bekerja dengan sebaik-baiknya di RSUD Kab.Klungkung. Pengakuan sebagai profesional oleh organisasi dan 
masyarakat akan menimbulkan perasaan bangga dan mendorong timbulnya kepuasan kerja, juga terdapat pengaruh komitmen profesional berpengaruh terhadap kepuasan kerja, artinya bahwa dengan semakin meningkatnya komitmen profesional maka kepuasan kerja perawat akan mengalami peningkatan. Peningkatan komitmen profesional tersebut ditunjukkan dengan adanya peningkatan pengetahuan, mendukung organisasi profesi (Fauzia \& Sutrisno, 2019).

Komitmen profesional memiliki nilai Beta sebesar 0,589 dan nilai Sig. sebesar 0,000, maka dapat dikatakan $\mathrm{H}_{2}$ diterima karena nilai Sig. 0,000<0,05. Kesimpulannya adalah bahwa komitmen profesional memiliki pengaruh positif dan signifikan terhadap motivasi kerja, dengan kata lain semakin meningkat komitmen profesional perawat Rumah Sakit Umum Daerah Kabupaten Klungkung, maka semakin meningkatkan motivasi kerja pada perawat Rumah Sakit Umum Daerah Kabupaten Klungkung, sehingga hipotesis ketiga diterima. Komitmen profesional terhadap motivasi kerja perawat di RSUD Kab. Klungkung mendapat hasil yang positif dan signifikan dikarenakan hasil yang diperoleh yaitu pekerjaan perawat yang sesuai dengan standar kualitas perawat di RSUD Kab.Klungkung, perawat dapat menyelesaikan tugas karena merasa memiliki tanggungjawab di RSUD Kab.Klungkung, perawat selalu hadir tepat waktu, profesi perawat menginspirasi untuk bekerja dengan sebaik-baiknya di RSUD Kab.Klungkung

Semakin tinggi motivasi kerja perawat maka semakin tinggi kepuasan kerja pada rumah sakit dan sebaliknya. Motivasi kerja merupakan dorongan terhadap perawat untuk melakukan pekerjaanya (Mus et al., 2018). Penelitian lain yang menyatakan bahwa motivasi perawat sangat dibutuhkan untuk menjaga kepuasan kerja mereka selalu tinggi yang akan berpengaruh positif terhadap output kerja yang diberikan. Suatu rumah sakit yang terus memberikan dorongan motivasi akan memiliki perawat yang puas dengan pekerjaannya. Motivasi kerja secara langsung berpengaruh positif terhadap kepuasan kerja. motivasi timbul dari tujuan seseorang untuk memenuhi kepuasannya (Lantara, 2018). Seseorang yang tidak termotivasi dalam bekerja tidak dapat menjalani pekerjaannya dengan sepenuh hati, hal inilah yang sering menjadikan seseorang tidak berhasil dalam kariernya. Gambaran yang akurat tentang hubungan ini adalah bahwa motivasi kerja menyumbang timbulnya kepuasan kerja yang tinggi. Parimita et al. (2018) dan Poceratu (2018) membuktikan bahwa motivasi kerja mempunyai pengaruh positif terhadap kepuasan kerja.

Motivasi kerja memiliki nilai Beta sebesar 0,391 dan nilai Sig. sebesar 0,025, maka dapat dikatakan $\mathrm{H}_{3}$ diterima karena nilai $\operatorname{Sig} 0,000<0,05$. Kesimpulannya adalah bahwa motivasi kerja memiliki pengaruh positif dan signifikan terhadap kepuasan kerja, dengan kata lain apabila motivasi kerja meningkat maka kepuasan kerja perawat Rumah Sakit Umum Daerah Kabupaten Klungkung akan semakin meningkat, sehingga hipotesis ketiga diterima. Motivasi kerja terhadap kepuasan kerja perawat di RSUD Kab. Klungkung mendapat hasil yang positif dan signifikan karena didukung oleh hasil perawat merasa membutuhkan keamanan dan keselamatan, antara lain keselamatan dan perlindungan dalam bekerja sebagai perawat di RSUD Kab.Klungkung dan 
Lingkungan kerja mebuat perawat termotivasi untuk bekerja lebih baik di RSUD Kab.Klungkung

Motivasi dapat membangkitkan semangat kerja perawat untuk bekerja lebih baik sehingga seorang perawat yang memiliki motivasi tinggi akan mempengaruhi kepuasan kerja menjadi tinggi. Kepuasan kerja tidak dapat dipisahkan oleh motivasi kerja yang seringkali merupakan harapan kerja perawat. Gambaran yang akurat tentang hubungan ini adalah bahwa motivasi kerja menyumbang timbulnya kepuasan kerja yang tinggi. Kepuasan kerja akan tinggi apabila keinginan dan kebutuhan perawat yang menjadi motivasi kerja terpenuhi. Hal ini mendukung penelitian yang dilakukan oleh Rahman et al. (2019), Puspa Dewi et al. (2019), Noviyanti et al. (2019), Andani \& Ardana (2020), Sylviana et al. (2020)

Berdasarkan hasil Uji Sobel menunjukkan bahwa hasil tabulasi Z = 4,569 $>1,96$ yang berarti variabel komitmen profesional berpengaruh positif dan signifikan terhadap kepuasan kerja Rumah Sakit Umum Daerah Kabupaten Klungkung dengan mediasi motivasi kerja, sehingga motivasi kerja merupakan variabel mediasi pengaruh antara Komitmen Profesional terhadap Kepuasan Kerja perawat Rumah Sakit Umum Daerah Kabupaten Klungkung, sehingga hipotesis keempat diterima. Komitmen profesional terhadap kepuasan kerja dengan motivasi kerja sebagai pemediasi mendapat hasil yang positif dan signifikan karena didukung oleh hasil bahwa perawat merasa membutuhkan keamanan dan keselamatan, yaitu membutuhkan keselamatan dan perlindungan dalam bekerja sebagai seorang perawat di RSUD Kab.Klungkung dan Lingkungan kerja mebuat perawat termotivasi untuk bekerja lebih baik di RSUD Kab.Klungkung. Selain itu juga dilihat dari pengaruh total memiliki nilai yang lebih besar dari pengaruh langsung sehingga komitmen profesional lebih baik mempengaruhi kepuasan kerja dengan motivasi sebagai pemediasi.

Suatu komitmen profesional pada dasarnya merupakan persepsi yang berintikan loyalitas, tekad dan harapan perawat dengan dituntun oleh sistem nilai atau norma yang akan mengarahkan orang tersebut. Hasil dari penelitian terdahulu menyatakan bahwa motivasi kerja berpengaruh positif dan signifikan terhadap kepuasan kerja perawat Bank Nagari (Can \& Yasri, 2016), hal ini dapat menjadikan komitmen profesional sebagai gagasan yang mendorong motivasi seseorang dalam bekerja. Kepuasan kerja akan tinggi bila keinginan dan kebutuhan perawat yang menjadikan motivasi kerja dapat terpenuh, kompensasi dari rumh sakit berupa penghargaan (reward) sesuai profesinya akan menimbulkan kepuasan kerja karena mereka merasa bahwa organisasi telah memperhatikan kebutuhan dan pengharapan kerja mereka. Penelitian sebelumnya mengungkap bahwa komitmen profesional mempunyai pengaruh secara tidak langsung melalui variabel mediasi motivasi terhadap kepuasan kerja, dengan adanya motivasi kerja, maka semangat kerja para auditor profesional bersedia dan rela untuk mengerahkan kemampuan dalam bentuk keahlian, ketrampilan, tenaga dan waktu demi tanggungjawab terhadap profesinya (Sulistyawati, 2016). Komitmen profesional berpengaruh positif dan signifikan melalui motivasi sebagai variabel intervening terhadap kepuasan kerja (Darnawati \& Dewi, 2019)

Implikasi teoritis dari hasil penelitian ini memberikan bukti pada pengembangan ilmu manajeman sumber daya manusia dan ilmu perilaku 
keorganisasian khususnya mengenai komitmen profesional, motivasi kerja dan kepuasan kerja yang mampu untuk membuktikan secara empiris teori yang digunakan pada penelitian ini yaitu teori dua faktor. Dalam pernyatannya terdapat hubungan individu yang berkaitan dengan pekerjaannya dan merupakan hubungan dasar dari seseorang dan sikap yang dimiliki seseorang terhadap pekerjaan tersebut atau pekerjaan yang telah menjadi bebannya yang dapat menentukan kesuksesan atau kegagalan pada diri seorang individu. Oleh karena itu, dengan adanya komitmen profesional yang semakin baik, maka motivasi kerja akan meningkat dan juga akan semakin meningkatkan kepuasan kerja perawat. Implikasi teoretis hasil penelitian ini juga dapat memberikan rujukan tambahan bagi penelitian selanjutnya yang membahas mengenai motivasi kerja, komitmen profesional dan kepuasan kerja.

Selain itu hasil penelitian ini dapat menjadi salah satu acuan bagi peneliti lainnnya yang ingin meneliti mengenai komitmen profesional, motivasi kerja dan kepuasan kerja. Secara teoritis penelitian ini juga memberikan pemahaman bahwa komitmen profesional yang rendah dan motivasi kerja secara nyata dapat meningkatkan kepuasan kerja, ketika komitmen profesional yang meningkat diperoleh oleh meningkatkan motivasi kerja, maka motivasi kerja yang dirasakan oleh menjadi semakin kuat sehingga berpotensi meningkatkan kepuasan kerja.

Berdasarkan penelitian yang telah dilakukan ditemukan beberapa keterbatasan dalam penelitian ini yaitu dimana memingat pandemi yang terjadi saat ini yaitu pandemi Covid-19 yang mempengaruhi pengisian kuesioner yang memerlukan waktu lama, dikarenakan perawat di RSUD Kab.Klungkung harus menyelesaikan pekerjaannya memingat banyaknya pasien yang masuk salah satunya pasien covid-19. Selain itiu penelitian ini menggunakan pendekatan cross section, dengan demikian temuan penelitian ini mungkin bisa berubah di waktu yang akan datang sedangkan lingkungan setiap saat akan berubah, sehingga penelitian ini penting untuk dilakukan kembali dimasa mendatang

\section{SIMPULAN}

Komitmen Profesional berpengaruh positif dan signifikan terhadap Kepuasan Kerja Rumah Sakit Umum Daerah Kabupaten Klungkung. sehingga hipotesis 1 diterima. Komitmen Profesional berpengaruh positif dan signifikan terhadap Motivasi Kerja Rumah Sakit Umum Daerah Kabupaten Klungkung, sehingga hipotesis 2 diterima. Motivasi Kerja berpengaruh positif dan signifikan terhadap Kepuasan Kerja Rumah Sakit Umum Daerah Kabupaten Klungkung, sehingga hipotesis 3 diterima. Motivasi Kerja merupakan variabel mediasi pengaruh antara Komitmen Profesional terhadap Kepuasan Kerja Rumah Sakit Umum Daerah Kabupaten Klungkung, sehingga hipotesis 4 diterima.

Secara teoritis, dilihat dari pengaruh langsung dan pengaruh total path analysis bahwa pengaruh total memliki nilai yang lebih besar jika dibandingkan dengan pengaruh langsung maka secara teoritis komitmen profesional akan lebih baik mempengaruhi kepuasan kerja apabila dimediasi dengan motivasi kerja.

Secara praktir, berdasarkan hasil yang diperoleh komitmen profesional dan motivasi kerja memiliki pengaruh yang positif dan positif signifikan terhadap kepuasan kerja perawat Rumah Sakit Umum Daerah Kabupaten Klungkung, ini 
menunjukan bahwa semakin meingkat komitmen profesional dan meningkatnya motivasi kerja akan dapat meningkatkan kepuasan kerja perawat Rumah Sakit Umum Daerah Kabupaten Klungkung. Pihak RSUD Kab.Klungkung harus tetap memperhatikan komitmen profesional perawat agar merasa termotivasi, sehingga akan meningkatkan kepuasan kerja perawat Rumah Sakit Umum Daerah Kabupaten Klungkung. Dari segi komitmen profesional indikator yang memiliki rata-rata terendah adalah saya akan menerima apapun jenis pekerjaan yang ditugaskan untuk dapat terus bekerja di RSUD Kab. Klungkung, yang harus dilakukan oleh perusahan adalah mencari tau keinginan perawat tentang pekerjaan apa yang mereka inginkan selama bekerja, agar mereka tidak salah dalam menempatkan posisi, sehingga dapat menurunkan kinerja, apabila mereka menempatkan posisi yang sesuai dengan pekerjaan mereka maka akan meningkatkan komitmen kerja mereka dan meningkatkan kepuasan kerja perawat. Dari segi motivasi kerja indikator yang memiliki rata-rata terendah adalah Saya senang diberikan pujian atas apa yang saya kerjakan di RSUD Kab.Klungkung, hal yang harus dilakukan oleh perusahaan adalah bukan sekedar memberikan pujan atas kinerja perawat perusahaan dapat memberikan reward, atau kesempatan mereka untuk meningkatkan jenjang karir mereka, agar perawat mereasa puas dalam melakukan pekejaan.

Bagi penelitian selanjutnya diharapkan mampu menambah variabel- variabel yang dapat mempengaruhi Kepuasan Kerja, serta mampu untuk memperluas ruang lingkup penelitian yang tidak hanya terbatas Rumah Sakit Umum Daerah Kabupaten Klungkung, atau dapat juga mengganti lokasi penelitian yang tidak hanya terfokus pada suatu lokasi penelitian, sehingga memberikan suatu pandangan yang lebih dan mampu diimplementasikan secara umum.

\section{REFERENSI}

Akase, R. G., Tahir, A., \& Made, A. (2021). The Effect of Organizational Commitmenton Financial Performance of Local Government. American Journal of Humanities and Social Sciences Research, 5(1), 86-100.

Akbar, A., Musadieq, M. Al, \& Mukzam, M. D. (2017). Pengaruh Komitmen Organisasional Terhadap Kinerja (Studi pada Karyawan PT Pelindo Surabaya). Jurnal Administrasi Bisnis (JAB), 47(2), 34.

Andani, N. L. S., \& Ardana, I. K. (2020). the Role of Work Satisfaction Mediates the Effect of Work Motivation on Employee Performance Logo House Bali. American Journal of Humanities and Social Sciences Research, 4(2), 45-51. https://www.ajhssr.com/wp-content/uploads/2020/01/G20424551.pdf

Can, A., \& Yasri. (2016). Pengaruh Motivasi Kerja, Kepuasan Kerja Dan Komitmen Organisasi Terhadap Kinerja Karyawan Pada Bank Nagari. EJournal UNP, 4(1), 1.

Chang, H.-Y., Lee, I.-C., Chu, T.-L., Liu, Y.-C., Liao, Y.-N., \& Teng, C.-I. (2019). The role of professional commitment in improving nurses' professional capabilities and reducing their intention to leave: Two-wave surveys. Journal of Advanced Nursing, 75(9), 1889-1901. 
Darnawati, \& Dewi, A. S. (2019). Pengaruh Komitmen Organisasional Dan Profesional Terhadap Kepuasan Kerja Pegawai Dengan Motivasi Sebagai Variabel Intervening Dikantor Dinas Pendidikan Kepemudaan Dan Olahraga Kabupaten Solok Selatan. IDEAS, 1(1), 1-17. https://doi.org/10.31219/osf.io/zshba

Fauzia, N., \& Sutrisno, T. (2019). Pengaruh Komitmen Organisasional Dan Profesional Terhadap Kepuasan Kerja Auditor: Motivasi Sebagai Variabel Intervening. $\quad J I M F E B \quad U B, \quad 1(1), \quad 1-8$. http://dx.doi.org/10.1016/j.cirp.2016.06.001\%0Ahttp://dx.doi.org/10.1016/j.p owtec.2016.12.055\%0Ahttps://doi.org/10.1016/j.ijfatigue.2019.02.006\%0Ah ttps://doi.org/10.1016/j.matlet.2019.04.024\%0Ahttps://doi.org/10.1016/j.matl et.2019.127252\%0Ahttp://dx.doi.o

Febrianti, Y. (2019). The Effect of Work Environment and Work Load on Nurses' Motivation in Bhayangkara Sespimma Polri Hospital, South Jakarta in 2018. International Journal of Economies, Business and Accounting Research (IJEBAR), 3(4), 435-456.

Jalagat, R. (2016). Job Performance, Job Satisfaction, and Motivation: A Critical Review of their Relationship. International Journal of Management and Economics, 5(6), 36-42. www.managementjournal.info

Kurniawan, I. P., \& Satrya, I. G. B. H. (2020). The Effect Of Employee Empowerment Of Compensation And Organizational Commitment To Satisfaction. American Journal of Humanities and Social Sciences Research, 4(3), 349-357.

Lantara, I. W. A. (2018). Pengaruh Motivasi Kerja Terhadap Kinerja Karyawan Dengan Kepuasan Kerja Sebagai Variabel Intervening Di Pt. Indonesia Tourism Development Corporation (Itdc). Jurnal Pendidikan Ekonomi Undiksha, 10(1), 231-240.

Mahendra, I. M. P., \& Suwandana, I. G. M. (2020). Job Satisfaction as a Mediating Variable Climate Organization to Influenced Turnover Intention. American Journal of Humanities and Social Sciences Research (AJHSSR), 1(7), 53-59. https://www.ajhssr.com/wp-content/uploads/2020/07/J20475359.pdf

Mitchell, R., Boyle, B., \& Stieglitz, S. Von. (2019). Professional Commitment and Team Effectiveness: A Moderated Mediation Investigation of Cognitive Diversity and Task Conflict. Journal of Business and Psychology, 34(1), 471483.

Mus, A., Koesmono, T., \& Wulani, F. (2018). Pengaruh Motivasi Kerja dan Komitmen Organisasional terhadap Kepuasan Kerja pada Perawat Rumah 
Sakit Umum Daerah Bobong. Kajian Ilmiah Mahasiswa Manajemen, 6(1), 110.

Noviyanti, E., Syofyan, E., \& Evanita, S. (2019). The Effect of Leadership, Work Motivation and Work Satisfaction on Performance of Employees of Education and Culture Department in Padang Pariaman. Advances in Economics, Business and Management Research, 97(Piceeba), 685-695. https://doi.org/10.2991/piceeba-19.2019.74

Parimita, W., Khoiriyah, S., \& Handaru, A. W. (2018). Pengaruh Motivasi Kerja Dan Kompensasi Terhadap Kepuasan Kerja Pada Karyawan Pt Tridaya Eramina Bahari. JRMSI - Jurnal Riset Manajemen Sains Indonesia, 9(1), 125144. https://doi.org/10.21009/jrmsi.009.1.09

Poceratu, I. C. (2018). Pengaruh Motivasi Kerja Terhadap Kepuasan Kerja Pegawai Lembaga Pembinaan Khusus Anak ( Lpka ) Klas Iia Ambon Dalam Perspektif Kristiani. Archipelago Engineering (ALE) 2018, 1(April), 163-167. Motivasi kerja, kepuasan kerja,Kerja adalah Ibadah. I.

Pradhana, M. B. S., \& Rasmini, N. K. (2020). The Effect of Organizational Commitment, Professionalism and Ethical Behavior on Auditor Performance in Public Accounting Firms in Bali Province. American Journal of Humanities and Social Sciences Research, 4(9), 67-71.

Puspa Dewi, Fikri, K., \& Fitrioc, T. (2019). The Effect of Work Motivation on Employees' Performance Mediated by Job Satisfaction at Pt. Bank Rakyat Indonesia TBK Rengat Branch Office. International Journal of Scientific Research and Management, 7(09), 1344-1358. https://doi.org/10.18535/ijsrm/v7i9.em04

Rahman, M. H., Fatema, M. R., \& Ali, M. H. (2019). Impact of Motivation and Job Satisfaction on Employee's Performance: An Empirical Study. Asian Journal of Economics, Business and Accounting, 1(March 2019), 1-10. https://doi.org/10.9734/ajeba/2019/v10i430112

Sablonnière, R. de la. (2017). Toward a Psychology of Social Change: A Typology of Social Change. Front Psychology, 8(1), 397.

Saputra, G. A. P., \& Suwandana, I. G. M. (2020). The role of job satisfaction mediates the relationship between compensation and career development on work motivation. American Journal of Humanities and Social Sciences Research, 4(12), 258-267. https://www.ajhssr.com/wpcontent/uploads/2020/12/ZH20412258267.pdf

Sari, P. P., \& Dewi, A. S. (2018). Pengaruh Komitmen Organisasional Dan Profesional Terhadap Kepuasan Kerja Dengan Motivasi Sebagai Variabel 
E-Jurnal Manajemen, Vol. 10, No. 8, $2021: 800-819$

Intervening Pada Pegawai Upt Dinas Kesehatan Puskesmas Air Bangis Pasaman Barat. IDEAS, 1(1), 1. https://doi.org/10.31219/osf.io/58pw7

Sulistyawati, A. I. (2016). Peran Pemediasi Motivasi pada Pengaruh Komitmen Organisasional dan Komitmen Profesional terhadap Kepuasan Kerja Auditor. Jurnal Riset Akuntansi Dan Perpajakan, 1(1), 1.

Sylviana, N., Ningsih, R. S. K., Hartati, Y., \& Yulianti, M. (2020). The impact of work motivation,job satisfaction and organizational commitment to organizational citizenship behavior(OCB) of the civil servants (ASN) of development and planning Bureau mentawai islands regency. American Journal of Humanities and Social Sciences Research, 4(4), 28-35. 